\title{
BLENDING MYTH AND MODERNITY IN THE GLOBAL CHINESE CINEMA: THE HONG KONG ACTION HERO IN ZHANG YIMOU-DIRECTED HERO
}

\section{Dhruba Karki*}

\section{ABSTRACT}

Zhang Yimou's Hero presents an action hero, yet in a slightly different cinematic mode than that of Stephen Chow-directed Shaolin Soccer to blend myth and modernity. In Yimou's martial arts cinema, Jet Li-starred Nameless hero uses martial arts to combat the king's adversaries, including Donnie Yen-starred Long Sky, Maggie Cheungstarred Flying Snow and Tony Leung Chiu-Wai-starred Broken Sword in the service to the Qin Dynasty (221 BC - $207 \mathrm{BC})$. The warrior hero's indigenous body art helps the Qin Dynasty transform the smaller warring kingdoms into a powerful Chinese Empire, a strong foundation of modern China with economic and military superpower. Like their western counterparts, including T1000 and Neo, the Hong Kong action heroes, such as the warrior hero and the Qin King have been refashioned in the Hollywood controlled twentieth-century popular culture. Different from their Hollywood counterparts in actions, the Hong Kong action heroes in Hero primarily use their trained bodies and martial skills to promote the Chinese civilization, an adaptation of the Hollywood tradition of technologized machine body. Reworking of myth and archetype in Nameless's service to the Qin Dynasty and the emperor's mission to incept the Chinese Empire, the Hong Kong action heroes appear on screen, a blend of tradition and modernity. The film industry's projection of the Chinese history with the legendary action heroes, including Nameless soldier and the Qin King globalizes the indigenous Chinese culture by using modern electronic digital technology, a resonance of the western technological advancement.

Keywords: The action hero, the Chinese-Hong Kong connection, myth, history, martial arts.

* Dr. Karki is an Associate Professor, Central Department of English, Kirtipur, TU. 


\section{THE HONG KONG CHINESE ACTION HERO}

In Zhang Yimou's Hero, the Jet Li-starred Nameless exploits his martial arts techniques to combat the three rivals in support to the Qin king Shi Huang's mission to unite the minor kingdoms. Yimou's warrior hero uses his physical body to fight Broken Sword, Flying Snow, and Long Sky, featuring Tony Leung, Maggie Cheung, and Donnie Yen, respectively. Cinematic representation of the action hero's spectacular feats highlights the Qin Dynasty (221 BC - $207 \mathrm{BC}$ ) in the formative process of the greater China with military and economic power at the turn of the millennium. Historically, the king of Qin embodies ambition and dynamic leadership for the greater interest of Chinese civilization, and the Kingdom of Qin stands for superpower among the warring states, including Zhao, Han Wei, Yan, Chu, and Qin. At that time, the king of Qin sustains strong national interest while aspiring to become the first emperor of the united imperial China. On the one hand, the Qin King believes in the formation of a stronger China for a greater national interest despite some of his adverse character traits. On the other hand, the warrior Nameless irrespective of the king's ruthlessness and over ambition sincerely supports the imperial leader for the noble cause of humanity. Yimou's global Chinese cinema with two action heroes, the king and the warrior reworks myth and archetype in processes of the quest for the self and the transformation of consciousness while blending fiction and history at the time China has been emerging global super power. In the historical setting of the Qin Dynasty, the action hero's exploit of kung fu skills and sword fight techniques unfolds an intersection of tradition and modernity, represented by the indigenous body art and commercial motion picture, respectively.

In Hero, Tony Ching Siu-Tung's action direction appropriates the flashback technique in documenting the significant historical events chronologically. In this light, it is important to observe how Stephen Teo, in Chinese Martial Arts Cinema: the Wuxia Tradition, describes the warrior's heroic endeavors and the Qin king's dynamic leadership in converting the minor kingdoms into a greater China some 2000 years ago:

The historicist subject of Hero is that the hero of the film must be a knight errant who is an agent of history, but, as Jia-xuan has 
asked, who is the hero of the piece? [...] Invariably the hero is a man rather than a woman, though in the film, there is a female assassin, played by Maggie Cheung, whose purpose of existence is to assassinate the tyrant but significantly, she doesn't even get close to her target. [...] The film gives us several knights-errant who are possible heroes. If we define a knight-errant as someone who is a master of the sword, the supposed villain of the piece, the Qin emperor who founded China as a nation, can be considered a knight-errant, and thus a hero, since he is shown to be a formidable swordsman himself. (185)

Nameless, with his actions and adventures, transforms himself into a heroic figure, championing the cause of the Qin dynasty. The hero's unconditional support to the Qin king epitomizes his sincere devotion to the authority with a noble mission to establish the first Chinese Empire. In his conversation with Broken Sword, Nameless hero expresses his patriotic feeling: "I am a citizen of Qin. I have a message from Sky" (Yimou). The hero in response to the call to action from the heavenly "sky" fights the king's enemies, using his swordfight techniques. The call to action comes from within the hero himself, reflecting the warrior's response to the invisible force, the divine, and the supernatural. In this light, Teo considers the night errant's engagements to transform smaller dynasties into the greater China. In this global Chinese movie, the warrior hero's sword-fights sequences parallel the ballet steps in the choreographic space. The warrior and the ballet dancer share a swirling body in circular structures to the rhythmic beat of background music. At their performances, the gravity of the body movement centers on the warrior's action on the battlefield and the dancer's performance in the choreographic space. At that point, spectators view the warrior's action body in dancing steps, and the dancer's smooth motion in physical actions. 
Figure 1: DVD Cover Image of Hero with Major Stars

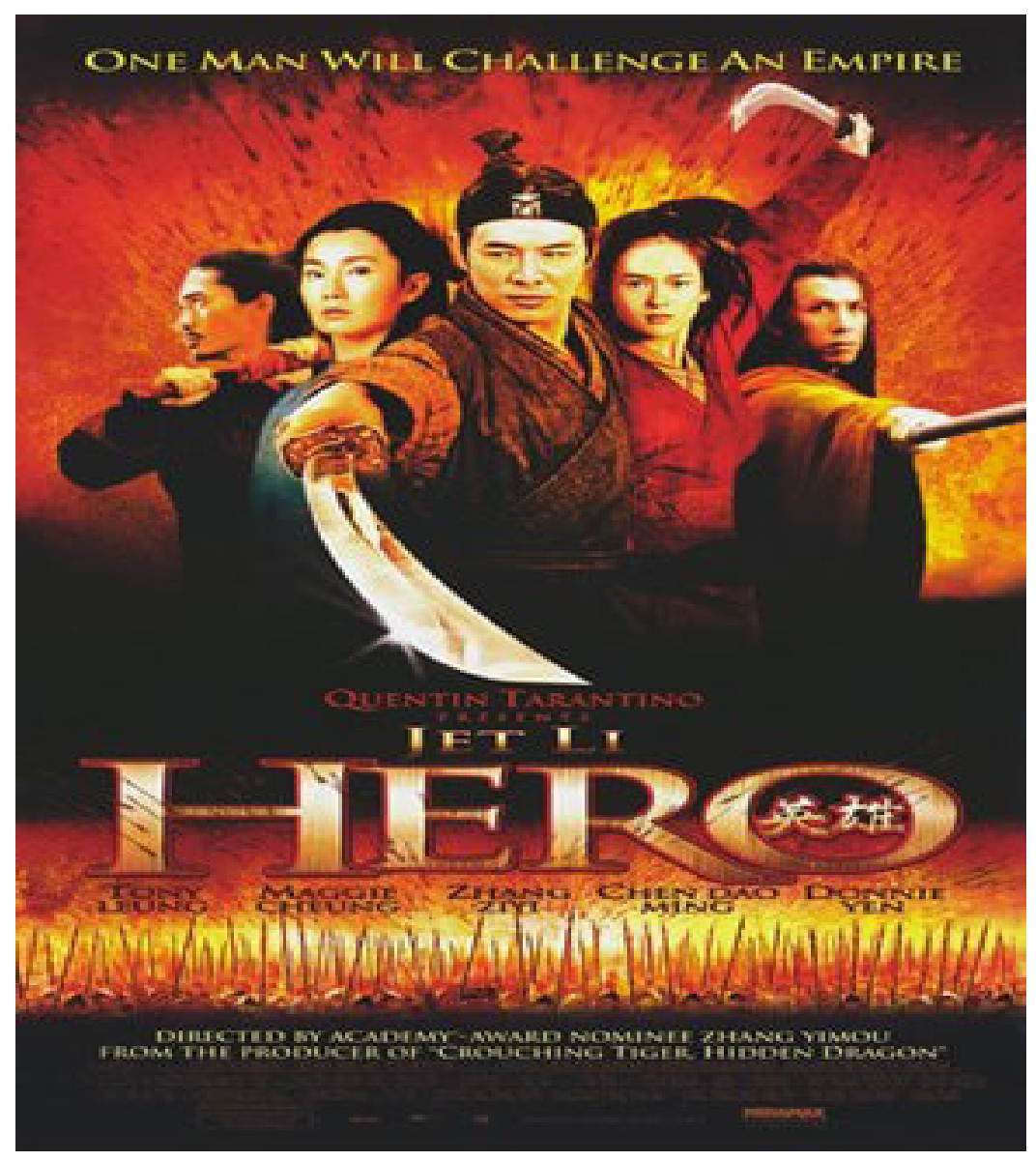

In Hero, Nameless's heroic endeavors in the service of the Qin king mythologize the supremacy of the Chinese civilization in the past. In this backdrop of reemergence of China, Gary Rawnsley and Ming Yeh Rawnsley in "Introduction" of Global Chinese Cinema: culture and politics of hero, examine Hero as a portrayal of Chinese national unity and cultural identity amidst rapid economic progress and cultural transformation after Xeng Xiaoping's promulgation of open door policy in 1979 (1). In the cinematic space, audiences share the action hero's use of martial techniques to annihilate the elemental forces, core components of species of all kinds. The cosmic unity with elements of fire, sky, air, earth and water are central to the making of human civilization, ranging from Prometheus's fire in the Greek myth to the medieval gunpowder. 
In narratives of the hero and heroism, the fire-theft has mythological connection. The hero, from the classic Greek Prometheus to the recent T1000, engages with the same elemental force in the service to mankind. Some of the historic landmarks, including the burning of Rome, the invention of medieval gunpowder, the innovation of the seventeenth-century steam engine and the modern day fireworks in industrialized cities have altogether contributed to the modern time civilizations. At one point, Siu Leung Li associates fire with creative process: "everything is wrapped up at first in a nebulosity of the enveloping micro-perception; and here we have $\mathrm{mind} /$ universe/materials/generation as the film's overall composite; these forces are combined in a chaotic way so as to pass even through human bodies for generation (286). In the way the Shaolin athlete brothers excel soccer in Stephen Chow's Shaolin Soccer, the action hero in Hero with the spirit from the Shaolin Buddhism and teachings of the Shaolin monks combats enemies of the Qin Dynasty. In his physical actions and sincere devotion to the kingdom, the hero in a process of integration the body, mind and spirit resembles the pious devout Shaolin Buddhist monks at the soccer field. In the way the athlete hero on the soccer field transforms himself into the Shaolin monk, the warrior hero unites the terrestrial and celestial, and mind and matter in his battles with the king's enemy force. Consequently, the powerful Qin Empire is established with the execution of the warrior and the unification of the warring kingdoms.

In his chivalric action in support to the Qin dynasty, Nameless of the 2002 global Chinese cinema experiences the unity of the body and the mind. The renunciation of the body for the cause of the greater China endows the warrior the title of the national hero. In that sense, the movie documents the historic unification of minor kingdoms under the leadership of the Qin king. In the movie, not only do the knight and the sword merge, but also the warrior and his country become one.

\section{THE IMAGE OF THE TRAGIC HERO}

The image of suffering body is a central motif in the heroic representation, ranging from the Greek Prometheus to the Judeo-Christian Jesus. In the Greek tradition, the hero, who should be technically dead, connects humans to the divine by his superhuman actions; people find spiritual connection to the buried hero through his real life actions. The buried hero connects the gods in the celestial sphere and humans in the 
mundane world, just as belief in spirituality connects the dead hero to humans. The death of the hero and the hero worship cult immortalize the courageous person that invokes the tragic image of the hero in the ancient Greek culture.

In The Birth of Tragedy out of the Spirit of Music (1872), Fredrick Nietzsche explicates organizing tendencies, represented by Apollo and Dionysus, by referencing the famous Wagnerian music. In Nietzsche's perception, the Wagnerian music and the Greek tragedy exhibit the dynamics between the Apollonian formulation and the Dionysian passion. In Nietzsche and Antiquity, Paul Bishop highlights the dynamics of the polar opposites of the Apollonian vision and the Dionysian music: reason and passion, appearance and reality, deception and truth, and representation and will, respectively. At the Dionysian festivals, Greeks are so much intoxicated that they temporarily lose their consciousness for primordial oneness, merging with the essence of reality and inner being (Bishop 278). At that moment, an individual is united with the primal unity, transcending all material realities and physical limits. Further, Bishop explicates the Dionysian response to a pertinent Apollonian question why people enjoy watching a tragedy on the stage, and the Apollonian address to the Dionysian queries of nausea and resignation. Moreover, Bishop reiterates the Nietzschean belief that the visual Apollonian representation of the Dionysian sound is the formative process of arts, sports, and cultures. The product of the Dionysian forces, the chorus when staged on the tragic theater, displays an individual's experience of the primordial oneness, allowing audiences to transform into satyrs, the mythical followers of Dionysus and connect to the god (280). The Greek tragic hero, from the Nietzschean Dionysus to the Sophoclean Oedipus, embodies the unity of the polar opposites represented by Apollo and Dionysus. Nameless in Hero and Steel Leg in Shaolin Soccer, in their concerted actions in the battlefield and the soccer field, display a unity of the Apollonian and the Dionysian forces. Playing the soccer with the kung fu mind is the Apollonian while the passionate intensity of sporting to experience the unity of action is the Dionysian impulse.

A performer's physical body in action exhibits the Nietzschean reconciliation of divergent but intertwined poles that operate simultaneously or alternatively in creative processes, such as playing, acting, and dancing. In "The Apollonian Eye and the Dionysian Ear," Steven Knoblauch infers the Apollonian vision and the Dionysian sound in line with the Jungian adoption of the Nietzschean insight in formulating a model of distinct 
personality types. Knoblauch examines the representation of the physical body in the Apollonian introvert and the Dionysian extravert personality types which produce dream images to organize the world, and internal images to correlate the inner self and the outer world (328). The Jungian introvert and extrovert types are the Apollonian formulation and the Dionysian extravagance of the primordial opposition. The psychological distinction corresponds to the Jungian ego-conscious and the Freudian idunconscious, significant creative forces based on mythological and psychic origins.

Sigmund Freud also affirms that the Greek tragedy is the product of the Apollonian-Dionysian interaction in the psychic space that transverses from the id-unconscious to the ego-conscious. In "Nietzsche, the Tragic-Real, and the Exquisite Corpse of Theory," Paul Mann terms the Apollonian as a force of representation, appearance, and individuation, and the Dionysian as a non-imagistic, ecstatic intoxication, and disruption of illusion. In juxtaposing the Apollonian and the Dionysian, Mann reaffirms the unification of the individual with the primordial oneness (17). Mann emphasizes on the unifying function of the Dionysian force that transcends all limits and boundaries, creating a spectrum for the primary oneness.

TheApollonian formulation of the Dionysian sensation distinguishes the Dionysian Greeks from the Dionysian barbarians. Greek arts, including music and tragedy, constituted of these two integrals, invoke the suffering body of the tragic action hero as embodiment of the rich Greek culture. Nietzsche affirms that music comes from suffering, an annihilation of the physical body into a sublime experience. The Buddhist treatment of suffering is different from the Nietzschean belief in the human evolution as well as the formation of art through sufferings. To cite Thick Nhat Hanh's remark human can gradually reduce its intensity by following the "the Middle Way, a path between practice of austerity and indulgence in sensual pleasure" (Hanh ix). Only after avoiding the life of such extremes and dualistic thinking, a strong attachment and an absolute rejection, can man be elevated to nirvana, the ultimate goal of all lives.

In Nietzsche and Buddhism, Robert Morrison investigates the confluence between the Buddhist principle and the Nietzschean conception of suffering. Morrison assesses the Buddhist and Nietzschean treatments of suffering as inherent condition of life, pointing suffering as a nexus between the material, worldly sansara and the immaterial, unworldly nirvana: 


\section{BLENDING MYTH AND MODERNITY IN THE GLOBAL ...}

The link between the samsaric (worldly life) and the nirvanic (the unworldly, total extinction of desire) aspects of dependent 'coorigination' is therefore dukkha (suffering), the first Noble Truth, which I would understand here as meaning that, in relation to the samsaric process, there is response of gradual satisfaction and disillusionment with it. [...] Thus, dukkha is the transitional stage between the samsaric and nirvanic aspects. (191-92)

In Buddhism, Morrison squares the four-fold sights connecting the sansaric to the nirvanic spheres. Among these, the first three can be grouped under the worldly and the last under the unworldly category. Siddhartha Gautama's quest of the cause of suffering was intrigued by the three figures: an old man, a sick man, and a corpse. Suffering leads individual to the ultimate truth of nirvana, a total absorption of the self into the other. Similarly, Steel Leg and Golden Leg in Shaolin Soccer and Nameless and the emperor in Hero in sporting and combat actions transcend the physicality and the mundane reality. The athlete's experience of the unity of action in the soccer field is the Apollonian individuation of the Dionysian ecstatic intoxication.

Morrison endorses a remarkable affinity between the two metaphysical traditions in terms of suffering and transformation. Suffering is intertwined and inseparable from lives in the Nietzschean and Buddhist belief systems, but the latter's focus is on the process of evolution from the samsara to the nirvana while the former emphasizes a process of transforming suffering into artistic works. Human being among numerous species in the universe undergoes multiple transformations, partaking in the birth-death-rebirth cycle, gradually evolves into a higher being. Man evolves in every successive life, becomes a better human being, and ultimately attains nirvana after the total extinction of desires and cravings.

The imagery of suffering in the Buddhist principle resonates the suffering of the tragic Christian hero. The dynamics of the Apollonian and the Dionysian forces generates the persona of the tragic hero in the Greek tradition that conforms to the Wheel of Life of Buddhism. In these lights, it is interesting to note that the central theme of balance between reason and passion, represented by the two Greek gods, is invoked in the Hollywood and Hong Kong action cinemas of the 1990s and 2000s. Nameless awaits the execution in the palace to set an example of the heroic sacrifice in Hero. Likewise, Steel Leg reorganizes the team while Golden Leg trains the 
athletes in the Shaolin Buddhist principles in Shaolin Soccer. Similarly, Neo saves humans from the invasion of machines in The Matrix and T1000 rescues Sarah and her son, embodiments of the future generations in Terminator 2.

\section{THE CINEMATIC REPRESENTATION OF ACTION HERO}

Hero unfolds the contemporary China's myths and realities with forest and lakeside fight scenes. In "Visual Effects Magic: Hero's Sydney Connection," included in Global Chinese Cinema, Mary Farquhar draws analogies between the lake scene and serenity of the fight, and the scenic beauty of the red birch forest and the most gorgeous setting of the martial arts film (191).

Figure 2: The Fight in the Forest Scene

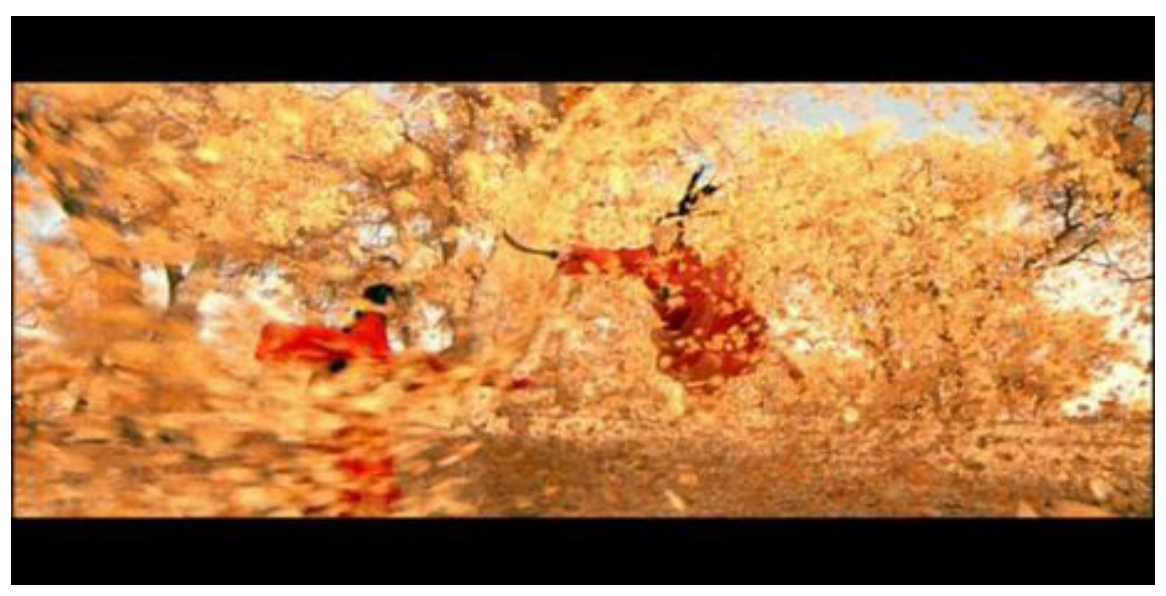

In the lakeside fight, the warrior hero, holding the fighting sword, merges into the water and leaves of the trees in the forest scene, a symbolic of China's rich cultural heritage and abundance of natural resources. Similarly, the Qin dynasty embodies the unity, power, and mission, just as the hero represents the building block of the greater China. Both the hero and dynasty prepare a strong base for the formation of the Chinese Empire at the turn of the century, renewal of the Chinese Civilization.

The cinematic transposition of the warrior hero's exploit of the indigenous body arts invokes a blend of myth and modernity. In "Recycled heroes, invented tradition and transformed identity," included in Gary Rawnsley and Ming-Yeh Rawnsley-edited Global Chinese Cinema: Culture and Politics of Hero, Yingjie Guo underscores relationships between the 
history and national identity in support to the hero's role in the nation building process:

Hero, in particular, not only returns to tradition but seeks to rediscover a traditional martial warrior type of heroism. When viewed in the light of emergent social values, transformed identities, new sociopolitical goals and alternative visions of China's future, the heroism of Hero and its unification theme have much to say about China's cultural and political change as well as shifting heroic attributes. [...] Hero is related to the quest for true Chinese heroes in postMao China not least because the film is centrally concerned with heroism. The quest stems from a perceived lack of heroic spirit of the kind that Hero depicts. (28)

Emblematic of a rapid progress in multiple fronts, Hero embodies China in a changing global context. The twentieth-century action movie and the popular body art visualize the contemporary China as an emerging superpower. A quasi-fictional narrative of Hero in the quest of the real heroes justifies China's endeavors to revive the Chinese civilization in modern context.

In National Identity, Anthony Smith examines Hero as cinematic reconstructions of Chinese identity in representations of heroes with true national spirit and rigorous physical actions. The hero's commitment to the Qin Empire embodies the shared values and the collective experience of Chinese citizens that constitutes a distinct repository of a national community (38). The Qin Empire evolves from an annihilation of the hero's physical body in Hero, just in the way the human race never ceases to exist with the destruction of the hero's body in Terminator 2. In Terminator 2, T1000 rescues a young boy named John Connor and his mother, Sarah Connor, from recurring invasion of machines. Similarly, the hero annihilates his physical body in order to strengthen the Qin Dynasty and build the greater Chinese Empire in Hero.

Mythological mode of history has a universal undertone. In Hero, the warrior's spectacular feats of swordfights have mythological connections. The hero in ancient Chinese civilization resurges during the Qin Dynasty some 2000 years ago. In a similar fashion, the athlete hero efficiently sports soccer with kung fu skills in Stephen Chow's Shaolin Soccer. The warrior renounces his body for the cause of the Qin Empire, and the soccer hero gives up his personal self in the interest of the Shaolin team. In The Hero 
with a Thousand Faces, Joseph Campbell explains that the hero sets his journey into the threshold of adventures, pays a price, and sacrifices his own life for a cause greater than himself (43). Like Steel Leg in Shaolin Soccer, Nameless in Hero in heroic rendition to the institution, the Kingdom of Qin and the Chinese national interest annihilates their physical his physical body.

In Hero, the hero's body combines arts and technologies to produce kinesthetic effects, resulting from movements of physical bodies. At the soccer game, the body of the player moves in tune with movements of notations of music; in the shooting, the camera pans to capture the character and the landscape inferring the relationship between the human hero and the physical space. Nameless hero in his swordfights and physical movements resembles the Shaolin athletes in their sporting actions on the soccer field. The warrior hero fights battles for the Qin Dynasty, and the athlete hero plays for the Shaolin team, exhibiting the combat skills and sportsmanship.

The athlete as the action hero and the warrior as the athlete share the common theme of sportsmanship and physical actions.

The closing shot of Hero sets a tone of the Greek heroic cult: "The nameless warrior was executed as the assassin but buried as the hero" (Yimou. Hero). The movie takes its title from the closing scene when the dead warrior, who sacrifices his life for the cause of the kingdom and the Qin Empire, is buried as the hero in order to set an example of the heroic action. The Qin King in his recognition of the national hero offers the state honor before executing him as per the law of the Qin. Broken Sword shares the vision to unify tia xia that prevents him from killing the king. Thought rejected by his lover Flying Snow, Broken Sword secures a position of the hero from for the king's mission to form the Chinese Empire (47). In Fung and Chan's assessment, Yimou's movie presents Nameless as a warrior who accepts death over life to champion the cause of the great China. Nameless embarks on a process of transformation from his identity as a loyal warrior into the self-made man, a resonance of the Greek hero cult. The Chinese action hero not only supports the king's ambition to become the first emperor of China but also the smaller kingdoms in their aspiration to get integrated under the Chinese Empire. Nameless in his heroic endeavors experiences what the heroes of history and mythology do in terms of their sacrifice of lives and renunciation of personal interest. 
In the Greek hero myth, the hero should be technically dead in order for him to be recognized, and Nameless conforms to the same hero worship tradition. The warrior is elevated to the stature of the hero, commanding other people's honor and worship while establishing the Holy Communion between the mortal and the divine. The death transforms the hero's ideals into meaningful purposes in the interest of the empire and people. The action epitomizes China's growing supremacy in the world and Chinese people's strong feeling of nationalism in the context of rapidly spreading forces of cultural globalization at the turn of the millennium.

Figure 3: Nameless Hero Among Warriors

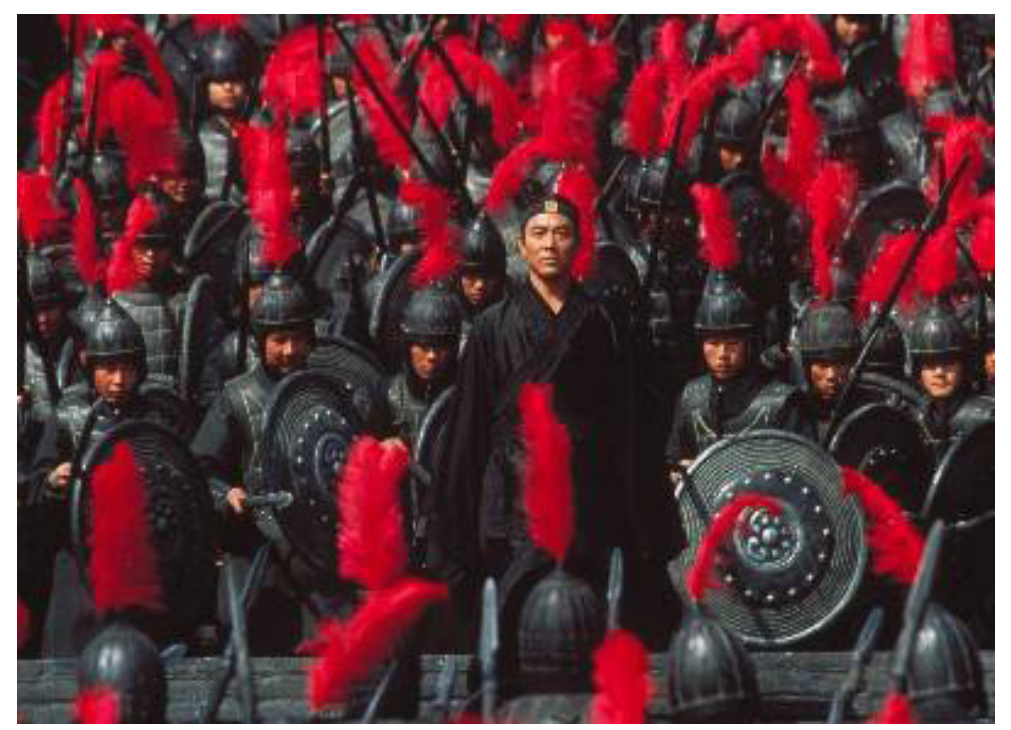

In Hero, Nameless with his actions stands for the courageous soldier, the loyal citizen, and the rising China. The self-sacrificing hero of this movie shares with the Hollywood sci-fi hero of Terminator 2 in representing the integration of the body and the universe of machines. In this Hollywood action movie, T1000 saves the procreative body of the mother and original source of life in by rescuing pregnant mother, Sarah Connar. In a similar way, the Hollywood sci-fi action hero protects the progeny of humans and the savior of mankind by saving the young boy, John Connar. The Hollywood action hero saves the mother creator and her creation when the world is under threats of machines and technologies. Similarly, the Hong Kong-Chinese action hero saves the dying dynasties, supporting the most powerful kingdom with its ambitious emperor. 
In Hong Kong Action Cinema, Bey Logan asserts the filming gunplay that combines ballistics with the balletic to give a new taste and sensibility to Hong Kong filmgoers (115). Norris and Woo exchange the cinematic techniques and artistic manifestations of the East and the West, representing Hong Kong-China and Hollywood-America, respectively. The Hong Kong action hero imbibes the chivalric hero's spears and arrows of the medieval European lore. Loyal to their lord or king, the virtuous medieval chivalric warriors appear on horsebacks to battle with enemies, demonstrating their physical prowess and patriotic feeling toward their ruler. In Hero, the loyal warrior Nameless with his sword confronts the enemies of the Qin Dynasty despite his awareness of the king's arrogance and ruthlessness. Similarly, Steel Leg in Shaolin Soccer follows Golden Leg's kung fu trainings and the Shaolin Buddhist principles. In these two movies, the heroes in the chivalric fashion reconcile past and present, tradition and modernity, and medieval Europe and contemporary Asia. Besides, the Hong Kong and the AngloAmerican action heroes share the body movements and rigorous actions with the modern ballet dancer.

In Dancing Machines, McCarren's highlights an effective amalgam of the artistic body and the body movement. Whether dancing or running on the athletic field, the performer concentrates on balance and systematic movement of the body. McCarren explores the ballet dance's underlying connections with other art forms, including movie and photography:

Dancing Machines provides a ground for asking what connects these forms across many domains: the possibility of the freezing or fragmentation of the image in instantaneity or time motion studies; the possibility of its condensation -- photographic ideogram or prose; the possibility of its projection -- in rhythmic seriality, in chorus line or cinema; and the "best speed" for choreographed labor or cinematic projection. What connects these forms, from work-science to dance, is a common culture, from physiological movement studies to cinema, and a common idea-economy of gesture. Across these forms, modernist economy of gesture takes two quite different shapes: one is a minimum effort, gauged to fit the machine; the other, a mechanical that is cosmic rather than comical, an oikos or system expansive rather than reductive. (10-11)

McCarren asserts that both the dancer's performance and the audience's perception of the dancing are connected with the machine. The 
machine imagery of dancing brings together audiences and artist in action. There are similarities between the movement of body and the operation of machine, a process that invokes impression of the dancing machine. Precisely, audiences perceive movements of machines as art forms, and dancing as the mechanical object.

In today's machine age, both dancing and sporting have been technologized with amplified sounds and digitized movements that create dazzling visual effects. McCarren examines the principle of economy applied in the mechanics of dancing and the operation of machine, saying that a minimum use of energy in the mechanical operation of the machine and that of physical strength in the dancing steps embodies the cosmic energy of machine that is condensed into a single body. In the cosmic energy of machine, which is condensed into a human motor, empowers the universe with the dancer's single pair of arms and legs. Besides, the economy of gesture defines and empowers the universe with the body movements defines as if carried by water (11). In McCarren's perception, the dance as distinctive human activity has a natural harmony and balance just as machine. He also identifies the process of actions and movements of body with flows and waves of water, and thus, affirming harmony and balance between the body art and natural phenomenon.

Drawing parallels between processes of the movement of the body and the movement of the water, McCarren reaffirms that "possibilities of the human body are sounded - although the movement qualities, rhythms, and steps remain limited" (97). The dancer and machine similarly maintain balance and harmony in their movements and aesthetic manifestations. Hence, both the operative process of machine and the dancer's mechanical movement are artistic and technological. Furthermore, the athlete's action sequences are organized in the tune with music, and the performer acts on the choreographic soccer field in Shaolin Soccer. The warrior Nameless's swordfights in the battlefield parallels with Steel Leg's sporting in the soccer field, as also with T1000's actions in the futuristic city and Neo's kung fu actions in the virtual space.

\section{THE TRANSCULTURAL JOURNEY: THE CHINESE HOLLYWOOD CONNECTION}

Like T1000 in Terminator 2, the action hero in Hero crosses the limits of the physical body to become the cyborg figure, transcending geographical boundaries and national borders. An ever-changing fluid-like 
image of T1000 in Terminator 2 exhibits the crossing of the divide between the real and the virtual, a process later followed by Neo in The Matrix later, and Nameless in Hero. In the automatic machine-like action figure and that of the digitized action hero in Terminator 2 and The Matrix embody transnational and trans-cultural imaginations, the Hollywood action hero resemble the Chinese Hong Kong hero's wuxia element. These heroes in Hong Kong martial arts and Hollywood sci-fi movies, when digitally mediated in the culture industry, become parts of lives of filmgoers rooted in diverse cultural and geographical settings.

Because of an increased exchange of people and merchandise across the Pacific Rim, the Hollywood products become popular beyond geographic borders of the US. Whether in the Asian Vietnam or African Haiti, American culture is followed because of the American imperial dominance over the world economy, business, and politics. In "General Introduction: What is Transnational Cinema," Elizabeth Ezra and Terry Rowden note:

As a marker of cosmopolitanism, the transnational at once transcends the national and presupposes it. For transnationalism, its nationalist other is neither an armored enemy with whom it must engage in a grim battle to the death nor a verbose relic whose outdated postures can only be scorned. From a national perspective, nationalism is instead a canny dialogical partner whose voice often seems to be growing stronger at the very moment that its substance is fading away. Like postmodernism and post-structuralism, other discourses that have complicated the notion of unmediated representation, transnationalism factors heterogeneity into its basic semantic framework. [...] The continued force of nationalism, especially nationalism grounded in religious cultures, must be recognized as an emotionally, especially charged component of the construction of the narratives of cultural identity that people at all levels of society use to maintain a stable sense of self. (4)

A continuous interaction between the local and the global prompts a transnational experience, creating conducive environment for cross-cultural interaction. The circulation of industrial products worldwide, including CDs, videos, and cassettes along with the expansion of the cinematic public space has instilled a sense of cultural hybridity and transnational experience. Audiences in their interactive processes with movies and videos imbibe 
cultures from different parts of the world, marking a recurring shift from the national to transnational spectatorship.

Yimou's Hero juxtaposes the body art and the motion picture, and the distinction between the two components reflects an evolving Chinese popular culture that retains the rich indigenous tradition while adopting currents of the changing world. In terms of its narrative, the movie traverses through the course of history and goes beyond the location of the Qin Dynasty, giving an impression of transnational and trans-historical journey of the action hero. In his action, the hero crosses the regional and geographical borders, going beyond the Qin Dynasty of the second century BC. The popular action movie unfolds the Chinese imperial history, focusing on the Qin Dynasty that plays a significant role in unifying several kingdoms.

The Hollywood-Hong Kong connection in the film industry has globalized indigenous cultural heritage along with modern cinematic arts. At times, Hollywood has contributed to the Hong Kong cinema; other times, Hong Kong has shared with Hollywood cinematic techniques. As an example of trans-cultural experience, the Hong Kong film industry has adopted the Hollywood trend of featuring mixed-race, hybrid stars by reworking the latter's cinematic techniques, and implementing innovative marketing strategies. The Hollywood adaptation of kung fu techniques in The Matrix, and the Hong Kong reworking of digitized fantasy in Shaolin Soccer exemplify a growing relationship between Hollywood and Hong Kong as a part of transnational experience and cross-cultural connection. John Woo introduced the quick-time Hollywood-style technique in Hong Kong action cinemas. Likewise, the Hong Kong action director Yuen WoPing not only choreographed numerous Hollywood sci-fi films, including The Matrix but also projected the action hero with indigenous Chinese root and changing popular culture. Next, Jet Li and Jackie Chan have become equally popular in the West while Michelle Yeoh is recognized as a Bond Girl through Tomorrow Never Dies (1997) outside Hong Kong. Then, Christopher Doyle from Australia choreographed the Chinese Hero.

Action heroes emerge from social transformations and political change, indicating the future course of scientific progress and technological innovation. In Hero, China's rapid progress in military and economic supremacy on the global stage has been represented by the warrior hero. Similarly, the closing scene of Shaolin Soccer with a newly wedded Shaolin 
couple on the cover page of Time suggests transnational media and transcultural characters.

The digitized movements of characters in The Matrix parallel with body movements of chief characters in Hong Kong martial arts cinemas. In Chasing Dragons: an Introduction to the Martial Arts Film, David West identifies the Hollywood connection of Shaolin Soccer in terms of the kung fu motifs and icons that athletes apply on the soccer field. In the final match, Sing's Iron Leg and Mui's Tai Chi, combine their martial arts techniques to score the winning goal. The Sing-Mui blend is analogous to Hong Hey Kwun's Tiger and Fong Sai Yuk's Crane styles used to defeat Che Kang in Heroes Two (179). The yin-yang union represented by hard and soft, tiger and crane, and high and low reinforce balance and harmony in the sports and arts amplifying that diametrically opposites can exist together.

In kung fu and gymnastics, an individual athlete exhibits personal development and rigorous training that shape the base of the western civilization, ranging from the ancient Greek to the contemporary American. In his athletic performances, as a gymnast and kung fu master, the action athlete hero portrays an amalgam of the Greek sports tradition and the Chinese body art, and both cover a substantial space in the Hong Kong Chinese movie Shaolin Soccer.

With the digital revolution in the film industry, the Hollywood film has expanded its cinematic production to appeal to audiences around the globe. Hollywood has become a leading entertainment industry influencing many of the world film productions. Similarly, Carl Boggs and Tom Pollard consider technology a determinant of the modernizing process of the Chinese world:

Modernism in the sphere of art both reflected and transcended the structures and ideologies of modernity linked to industrialism, technology, and bureaucratic organization-structures and ideologies theoretically elaborated by the great social and political theorists of the Enlightenment. Cultural modernism simultaneously embraced and questioned the power of commodity, a conflicted dualism that further extends to its stance toward technology. (169)

Modernism marks a departure from the traditional stance based on the Enlightenment's excessive stress on reason. Numerous Hollywood films display the crossing of the divide, going beyond the modernist stress on technology and industrialization, revamping a broader cultural alliance. 
Blending myth and modernity, Yimou's Hero revives mythological heroes in historical context at the time China has become of the world superpower along with the United States. The Chinese supremacy in popular culture justifies the Qin King's vision endorsed by Nameless hero.

\section{THE HONG KONG MARTIAL ARTS HERO: THE CHINESE- HOLLYWOOD CONNECTION}

Hong Kong cinemas amplify commercial motive and domestic specificities. Laikwan Pang stresses on the necessity of an in-depth investigation into the cultural complexity for a clear understanding of the Hong Kong action hero. In Pang's conception, archetypes and ideologies of masculinities represented in Hong Kong action cinema include Jackie Chan's heroic macho, docile and domestic attitudes, and Stephen Chow's performance of a clown and God (3). In their roles and appearances, Bruce Lee, Jackie Chan and Jet Li exhibit the patriarchal ideologies pertaining to masculinities within the cinematic space. Whereas Bruce Lee-starred movies like Chinese Connection (1972) and The Big Boss (1971) barely present female characters, Jet Li hardly appears with heroines in The Enforcer (1976) and Fist of Legend (1994). Even if the women characters are represented, action sequences focus on their revenge of the murder of their master like in Fist of Legend or their rigorous physical prowess in defending their turf in Kung Fu Hustle (2004).

Yimou's Hero reassesses the importance of the Qin king and the warrior hero in the building of the greater China over the course of history. This Hong Kong action movie reposes cultural hybridity of scifi and tech-noir transpires from the Weimar Expressionist cinema to the recent techno-thrillers with prominence to the visual over the auditory and action over rhetoric. Modern audiences often take impressions of the visual spectacle formed of various colors and computer graphics. Some of the action directors proposing a radical departure from the modernist trend in the filmmaking include Woody Allen, Quentin Tarantino and John Waters. The Hollywood sci-fi action film exhibits a gradual shift from the modernist focus on techno-centered rational subject to the postmodernist challenge to the connection between the self and the other. The postmodernist subversion of the modernist distinction between the self and the body, and human and machine posits disorder, uncertainty, and the darkness. In this paper, the action hero appears in the nexus between human and machine, light and darkness, and conscious and the unconscious. The action hero sets out to the quest journey to the unknown zone, the uncharted territory of the darkness and uncertainty. 


\section{WORKS CITED}

Andy, Watchowski and Larry Watchowski, dir. Matrix Revolutions. Home Video, 2003. Print.

Bishop, Philip E. Adventures in the Human Spirit. Fifth Edition. New Jersey: Prentice Hall, 2007. Print.

Boggs, Carl and Tom Pollard. "Postmodern Cinema and Hollywood Culture in an Age of Corporate Colonization." Democracy \& Nature: The International Journal of Inclusive Democracy 7.1 (2001): 159-181. Academic Search Complete. EBSCO. Web. 1 Feb. 2011.

Bordwell, David. Planet Hong Kong: Popular Cinema and the Art of Entertainment. Cambridge, Massachusetts: Harvard University Press, 2000.

Campbell, Joseph. The Hero with a Thousand Faces. New Jersey: Princeton U P, 1973. Print.

Cameron, James, dir.. Terminator 2: Judgment Day. Perf. Arnold Schwarzenegger, Linda

Hamilton, and Edward Furlong. Le Studio Canal/ Pacific Western, 1991. DVD.

Capra, Fritjof. The Tao of Physics: An Exploration of the Parallels between Modern Physics and Eastern Mystics. Boston: Shambhala, 2000. Print.

Cho, Stephen, dir. Shaolin Soccer. Perf. Stephen Chow and Wei Tse. Warner Home Video, 2001. DVD.

Ezra, Elizabeth, and Terry Rowden. Transnational Cinema: The Film Reader. London: Routledge, 2006. Print.

Farquar, Mary. "Visual Effects Magic: Hero's Sydney Connection.” Ed. Gary D, Rawnsley and Ming-Yeh T. Rawnsley. Global Chinese Cinema: The Culture and Politics of Hero. New York: Routledge, 2010. 184-97. Web. 1 June 2010.

Guo, Yingjie. Recycled heroes, invented tradition and transformed identity. Ed Gary Rawnsley and Ming-Yeh Rawnsley-edited Global Chinese Cinema: culture and politics of hero Routledge, 2010. Print.

Hanh, Thick Nhat. Beyond the Self Teachings on the Middle Way. Berkeley, California: Parallax Press, 2009. Print.

Joseph Campbell on Power of Myths with Bill Moyers. United States: Mystic Fire Video, 2001. DVD. 
Jung, Carl \& Gerhard Adler, et al. The Archetypes and the Collective Unconscious and Archetypes. Vol IX Part 1. Trans. R F C Hull. Princeton: Princeton U P, 1981. Print.

Joseph, May. "Kung Fu Cinema and Frugality." Nomadic Identities: the Performance of Citizenship. Minnesota: University of Minnesota Publishers, 1999. Print. 49-68.

Knoblauch, Steven H. "The Apollonian Eye and the Dionysian Ear." Psychoanalytic Inquiry 26.3 (2006): 326-343. Academic Search Complete. EBSCO. Web. 2 Feb. 2010.

Li, Siu Leung. "The Myth Continues: Cinematic Kung Fu in Modernity. Ed. Meaghan Morris." Ed. Siu L. Li and Stephen C. Chan. Hong Kong Connections: Transnational Imagination in Action Cinema. Durham: Duke University Press, 2005. Print. 49-62.

Logan, Bey. Hong Kong Action Cinema. New York: Overlook Press, 1995. Print.

McDonogh, Gary and Cindy Wong. Global Hong Kong. Britain: Routledge, 2005. Print.

Minz, Marilyn D. The Martial Arts Films. Stamford, CT: A. S. Barnes and Company, 1986. Print.

Morrison, Robert. Nietzsche and Buddhism: A Study in Nihilism and Ironic Affinities.Oxford: New York: Oxford U P, 1999. Print.

Raglan, Lord. The Hero: A Study in Tradition, Myth, and Drama. New York: Vintage Books, 1965. Print.

Rank, Otto. Art and Artist: Creative Urge and Personality Development. New York: Agathon Press, 1968. Print.

Smith, Anthony. National Identity. Nevada: Nevada UP, 1993. 38. Print.

Teo, Stephen. Chinese Martial Arts Cinema: the Wuxia Tradition. Edinburgh: Edinburgh University Press, 2009.

West, David. Chasing Dragons: An Introduction to the Martial Arts Film. London: I. B. Tauris, 2006. Print.

Zhang, Yimou, dir. Hero. Perf. Jet Li and Maggie Cheung. Quentin Tarantino, 2002. DVD. Web. 